\title{
Quando é dia de futebol: A prosa e a poesia em Carlos Drummond de Andrade
}

Marcelo Rodrigues de Melo Palmeira ${ }^{1}$

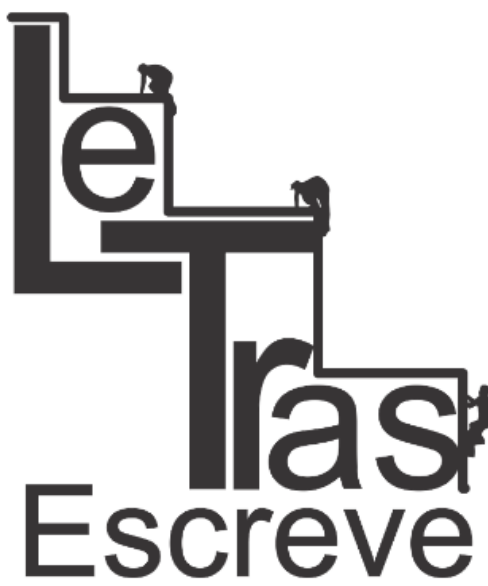

(ISSN 2238-8060)

\section{A prosa do futebol em Drummond}

Ao apresentar os conceitos de "futebol de prosa" e "futebol de poesia" em minha dissertação, elaborando uma distinção precisa entre os dois, porém entrelaçando-os e demonstrando que o futebol mundial passou, possivelmente a partir de meados dos anos 1980, por uma hibridização entre os dois estilos, irei discutir, nestes dois capítulos, as relações entre esses conceitos e os textos de Carlos Drummond de Andrade reunidos na obra Quando é dia de futebol.

\footnotetext{
${ }^{1}$ Mestre em Literatura Brasileira pela Universidade Federal de Minas Gerais (UFMG).
}

https://periodicos.unifap.br/index.php/letras

Macapá, v. 6, n. I, Io semestre, 2016. 
Neste primeiro capítulo, abordarei a relação entre o "futebol de prosa" e a obra drummondiana; para que no segundo capítulo eu possa apresentar a relação entre a obra de Drummond e o "futebol de poesia".

Para iniciar a discussão sobre a relação entre o "futebol de prosa" e a obra de Drummond, recorro a um trecho do texto do professor e pesquisador da UFMG Elcio Cornelsen, intitulado "A linguagem do futebol segundo Pasolini: 'futebol de prosa' e 'futebol de poesia'" em que, seguindo a esteira de Pasolini, são apresentadas sinteticamente as características do "futebol de prosa":

...de acordo com Pasolini, o "futebol de prosa" se fundamentaria menos na técnica individual, mas sim na organização tática centrada no coletivo: "a retranca e a triangulação (que Brera chama geometria) é futebol de prosa: baseia-se na sintaxe, isto é, no jogo coletivo e organizado, na execução racional do código" (PASOLINI, 2005). Sendo assim, - "gol" seria o momento díspar e singular dentro dessa "sintaxe": "o seu único momento poético é o contrapé seguido do gol (que, como vimos, é necessariamente poético). Em suma, o momento poético do futebol parece ser (como sempre) o momento individualista (drible e gol; ou passe inspirado)" (PASOLINI, 2005)2.

Em relação ao "futebol de prosa", vários treinadores, para não dizer a grande maioria, priorizam em seus trabalhos o treinamento tático, que seria, basicamente, o posicionamento dos jogadores em campo e a movimentação do time como um conjunto, baseados na convicção de que as jogadas coletivas e ensaiadas se sobressaem às jogadas individuais.

Como "futebol de prosa", o jogo mais pragmático se tornou rotina nos gramados espalhados pelo mundo afora, deixando para alguns poucos momentos o futebol mais poético. Na obra de Drummond, as crônicas e as cartas possuem, em seu estilo de escrita, uma característica análoga a esse estilo de jogo. Vários trechos demonstram essa afirmação. Como, por exemplo, a crônica

${ }^{2}$ CORNELSEN, 2006, p. 187-188.

https://periodicos.unifap.br/index.php/letras

Macapá, v. 6, n. I, Io semestre, 2016. 
intitulada "Mistério de bola", publicada no Correio da Manhã, no dia 17 de junho de 1954:

Finalmente, a grande ilusão do gol confere alta dignidade à paixão popular, que não visa a um resultado positivo e duradouro no plano real, mas se satisfaz com uma abstração: vinte e dois homens se atiram uns contra outros, e era de esperar que os mais combativos ou engenhosos, saindo triunfantes, deixassem os demais no campo, arrebentados. Não. O objeto de couro transpõe uma linha convencional, e o que se chama de vitória aparece aos olhos de todos com uma evidência corporal que dispensa a imolação física. Não podemos acusar de primitivismo aos que se satisfazem com este resultado ideal. ${ }^{3}$

Neste trecho, um estilo mais prosaico está presente através da forma como o texto é escrito, ao analisar racionalmente a paixão pelo futebol. A escrita é objetiva e bem organizada, com o intuito de

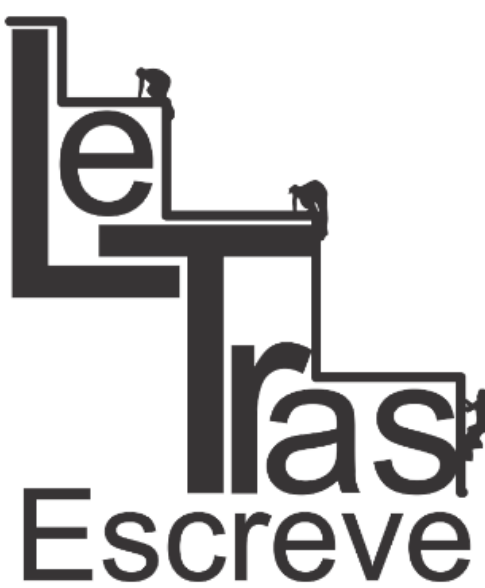

(ISSN 2238-8060) demonstrar claramente a dimensão simbólica do jogo, "que não visa a um resultado positivo e duradouro no plano real". A racionalidade e o encadeamento lógico das ideias, então, se adaptam perfeitamente à escrita em prosa, com sua linearidade e sua ordenação.

Continuando na obra de Drummond, mais um trecho da crônica "Mistério de bola", em que ele fala de sua saudade pelas antigas narrações dos jogos, nas quais eram usados mais recursos poéticos:

Assim gostaria eu de ouvir a descrição do jogo entre brasileiros e mexicanos, e a de todos os jogos: à maneira de Homero. Mas o estilo atual é outro, e o sentimento dramático se orna de termos técnicos. Mesmo assim, quando o cronista especializado informa que o Botafogo "não estava numa tarde de grande inspiração" ou que Zizinho "se desempenhou com o seu habitual talento", fico imaginando que há no futebol valores transcendentes, que nós, simples curiosos, não captamos, mas que o bom torcedor vai intuindo com a argúcia apurada em uma longa educação da vista. ${ }^{4}$

\footnotetext{
${ }^{3}$ ANDRADE, 2014, p. 20.

${ }^{4}$ Idem, p. 19.
}

https://periodicos.unifap.br/index.php/letras

Macapá, v. 6, n. I, Io semestre, 2016. 
$\mathrm{Na}$ crônica acima, tem-se a descrição da forma como Drummond gostava de ouvir os jogos de futebol, sendo que essa é apresentada de maneira simples e direta na forma de escrever e mais uma vez dialoga com o estilo de jogo pasoliniano do "futebol de prosa". Apesar disso, têm-se no trecho alguns momentos poéticos, como na evocação a Homero, que redunda numa relação metafórica entre o jogo e as guerras e feitos heroicos das epopeias gregas, e no eufemismo que diz que o time do Botafogo "não estava numa tarde de grande inspiração". Esses "momentos poéticos" indicam que, mesmo na prosa, a poesia está presente para dar um caráter literário ao texto.

Na crônica intitulada "Calma, torcedor", publicada no jornal Correio da Manhã, no dia 31 de março de 1959, o escritor mineiro pede calma aos torcedores brasileiros, visto que o futebol não é a atividade mais importante da vida, mesmo com toda a euforia por parte da população brasileira pela conquista da Copa de 1958:

Somos campeões do mundo, é verdade, mas isso não nos
deve torturar mais do que, por exemplo, as misérias do
subdesenvolvimento. O campeão não é campeão vinte e
quatro horas por dia; chega uma hora de calçar os chinelos, e
bocejar; um tempo de ver as flores; tempo de não sofrer mais
do que o estritamente necessário, e desconfiar das glórias
incômodas. De resto, não somos sessenta milhões de
campeões, o que inflacionaria a espécie; eles são apenas onze
e seus reservas. Penso nas coronárias e sugiro (diante do
espelho): Calma, torcedor. ${ }^{5}$

No trecho acima, mais uma vez temos a presença de um estilo prosaico, visto que o autor descreve suas impressões sobre a vitória da seleção na Suécia de maneira organizada e racional. Ao falar sobre como o torcedor deveria absorver a vitória, Drummond acredita que ele teria que recepcioná-la de forma tranquila, sem se entregar à euforia e à paixão, comumente associadas ao "futebol de poesia”. Tem-se, aí, um aprendizado sobre o futebol: mesmo sendo considerado o esporte mais popular do mundo, não se pode

${ }^{5}$ ANDRADE, 2014, p. 29.

https://periodicos.unifap.br/index.php/letras

Macapá, v. 6, n. I, Io semestre, 2016. 


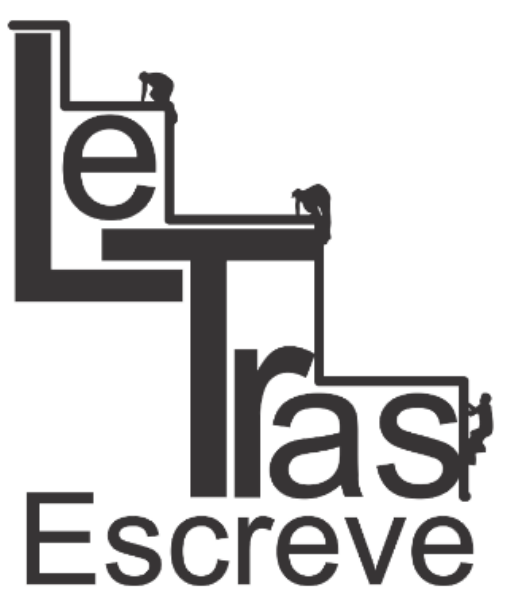

(ISSN 2238-8060)

despejar sobre ele todos os sentimentos, sejam as alegrias ou as frustações. Uma característica marcante das crônicas do poeta é justamente esse "filosofar" sobre o esporte, e não apenas analisá-lo tecnicamente, como é mais comum nas crônicas e colunas de opinião de muitos outros autores.

Quando se coloca a questão da "filosofia" nos textos drummondianos, aponta-se para a abrangência de seus comentários a respeito de todo o conteúdo que o futebol proporciona aos seus torcedores. Desde a forma como as pessoas se comportam perante uma vitória ou uma derrota de seu time, até qualquer impacto que o futebol pode proporcionar na vida cotidiana de cada apaixonado por ele. Esses comentários, colocados geralmente de maneira sutil, muitas vezes de forma indireta, é que são os momentos "filosóficos" do autor. E esses momentos são de grande valia, pois é a partir deles que o poeta faz suas críticas em relação ao mundo do futebol e ao contexto político que permeava seus textos, em especial o regime militar.

Para destacar algumas dessas "filosofias" da obra de Drummond, podemos citar a crônica "Jogo a distância". Dois dias depois de o Brasil perder seu primeiro jogo na Copa do Mundo de 1966, para a Hungria, por $3 \times 1$, ele escreve o texto, publicado no Correio da Manhã no dia 17 de julho de 1966, no qual vários torcedores comentam a atuação dos jogadores. Suas falas são verdadeiras aulas de filosofia sobre o futebol:

Aquele procurava não sofrer muito:

- Eu sei que futebol é assim mesmo, um dia a gente ganha, outro dia a gente perde, mas por que é que, quando a gente ganha, ninguém se lembra de que futebol é assim mesmo?

(...)

João Brandão continuava sereno:

- Perder é uma forma de aprender. E ganhar, uma forma de esquecer o que se aprendeu. Há um ditado nas Bateias que diz:

- "Muita chuva é sinal de sol". ${ }^{6}$

${ }^{6}$ ANDRADE, 2014, p. 53-54.

https://periodicos.unifap.br/index.php/letras

Macapá, v. 6, n. I, Io semestre, 2016. 


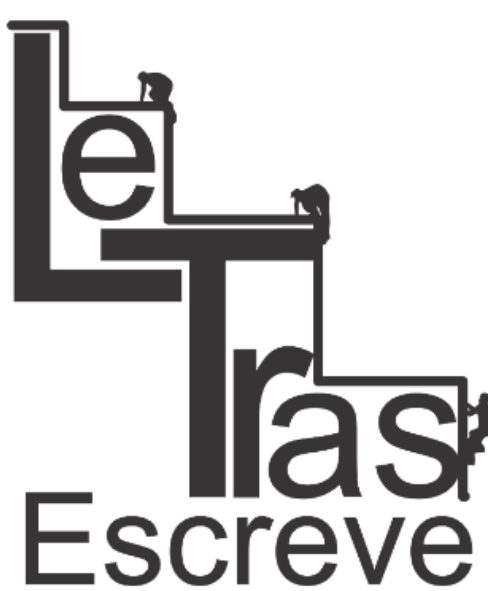

(ISSN 2238-8060)
No trecho acima, os comentários dos torcedores nos mostram que o esporte, através das vitórias e das derrotas, consegue levar aos seus amantes determinados aprendizados que servem para a vida cotidiana. No caso de uma vitória, as pessoas, muitas vezes, acabam se sentindo mais eufóricas, o que gera uma grande satisfação e um grande prazer. Ao mesmo tempo, porém, essa mesma vitória nos faz esquecer os nossos aprendizados, muitas vezes devido à própria euforia que ela causa. E esse esquecimento pode trazer graves consequências, visto que determinados "erros" cometidos ao longo da vida podem nos trazer grandes prejuízos. No caso de uma derrota, além de aprendermos através da dor da perda e da frustação que ela causa, um sentimento de inoperância pode pairar na cabeça do torcedor. Esses sentimentos nos fazem, na maioria das vezes, não cometer os mesmos erros que cometemos anteriormente.

As cartas de Drummond publicadas em Quando é dia de futebol também oferecem oportunidades para relacionar futebol e literatura pelo viés da prosa. Numa carta para seu neto Luis Mauricio, datada no dia 20 de junho de 1965, o poeta destaca que, na Copa de 1966, o Brasil encontraria muitas dificuldades para enfrentar as seleções que praticavam um futebol mais fechado, com mais marcação do que criação:

Nossos jogadores não se empenharam a fundo nesse primeiro e único jogo, e a experiência não valeu como preparação para os matches da Copa do Mundo de 1966, pois em nenhum eles serão disputados em campos dessa natureza, e além do mais o pessoal argeliano é fraco na bola. O que parece ter sido útil para nós foi o estilo argentino de ferrolho, que provavelmente será adotado por todo o mundo na Copa de 66, de sorte que vai ser difícil praticar o jogo bonito que gostamos de mostrar. Mas sempre se dará um jeito para tornar divertido o espetáculo, quando Pelé e Garrincha estiverem no campo. Mandarei a você, de vez em quando, alguns recortes de jornais, contando as novidades esportivas. ${ }^{7}$

${ }^{7}$ ANDRADE, 2014, p. 158-159.

https://periodicos.unifap.br/index.php/letras

Macapá, v. 6, n. I, Io semestre, 2016. 


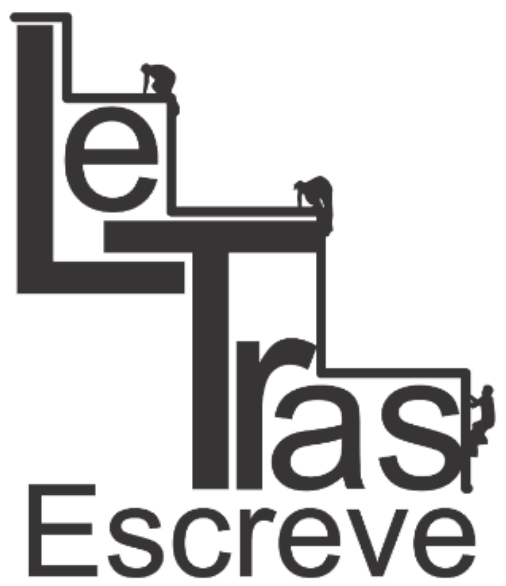

(ISSN 2238-8060)
O "futebol de prosa", caracterizado por um estilo de jogo mais objetivo e direto, sem espaço para grandes inventividades, dialoga diretamente com o trecho da carta acima, visto que o objetivo de sua escrita é transmitir uma mensagem direta e objetiva, informando o neto sobre a preparação da seleção brasileira para a Copa de 1966. Escrevendo descompromissadamente a seu neto e adotando um gênero eminentemente prosaico como a correspondência, o autor não se preocupa em conferir poeticidade ao texto, embora mostre sua predileção pela poesia do futebol, praticada pelos jogadores brasileiros, capazes de tornar o espetáculo mais "divertido" - vale dizer, mais poético.

Em outra carta, enviada a seu neto Carlos Manuel, no dia 13 de julho de 1966, Drummond volta a demonstrar seu apreço pelo "futebol de poesia" dos jogadores brasileiros, reclamando que a ordem dos adversários é "baixar o sarrafo" na nossa seleção, que era tecnicamente superior às outras de seu grupo: ${ }^{8}$

\begin{abstract}
Estou the escrevendo sob a agradável impressão da estreia da Seleção Brasileira na Copa do Mundo. O primeiro gol do campeonato foi feito por mestre Pelé, como você deve ter sabido, e a vitória obtida, modesta mas confortadora, permite esperanças de uma atuação eficiente nas outras partidas. Isso se as outras seleções não aleijarem nosso pessoal, pois parece que a ordem é baixar o sarrafo. Esportivamente, desejo boa sorte à seleção argentina (nesta manhã em que escrevo não se realizou ainda o encontro com a Espanha). ${ }^{9}$
\end{abstract}

No trecho acima, percebe-se, em relação ao conteúdo do texto, uma manifestação contra o anti-jogo para impedir a realização do "futebol de poesia". Já em relação aos aspectos formais do texto, a presença da prosa está intrinsecamente ligada ao gênero epistolar,

${ }^{8}$ Nessa Copa, realizada na Inglaterra, o Brasil não passou da primeira fase, pois não conseguiu impor seu estilo de jogo, que havia encantado nas Copas de 1958 e 1962. Pelé e Garrincha estiveram juntos apenas no primeiro jogo (Brasil $2 \times 0$ Tchecoslováquia). No segundo jogo (Brasil $1 \times 3$ Hungria), Pelé esteve ausente e, no terceiro (Brasil $1 \times 3$ Portugal), Garrincha esteve ausente. Com isso e mais a desorganização na preparação, a seleção canarinho não conseguiu desenvolver o seu melhor futebol.

${ }^{9}$ ANDRADE, 2014, p. 159. 


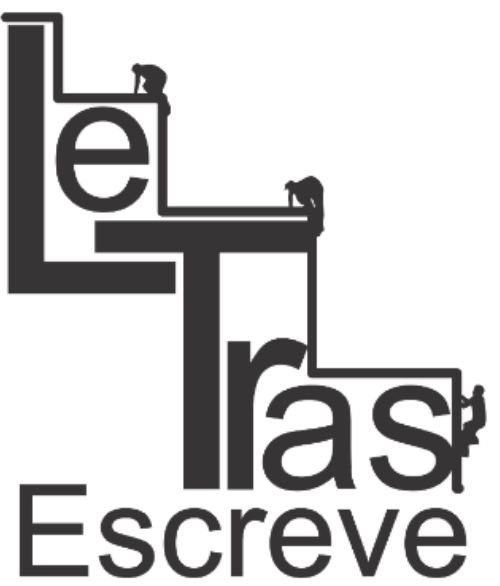

(ISSN 2238-8060)

marcado pelo desejo de comunicação informal com o interlocutor, sem "dribles"10 ou metaforizações que desloquem o leitor para algum outro sentido no texto.

Porém, assim como o "futebol de prosa" necessita inevitavelmente de um momento poético para atingir sua finalidade, a escrita em prosa também precisa de alguns lances poéticos para ser alçada à condição de texto literário. Na carta acima, esses lances poéticos estão presentes, por exemplo, nas expressões: "se as outras seleções não aleijarem nosso pessoal", uma hiperbolização dos efeitos do jogo violento sobre os atletas; e "baixar o sarrafo", uma metáfora para os lances violentos que ocorrem numa partida.

Além das figuras de linguagem apontadas acima e de outras formas de romper a linearidade da prosa, tem-se uma figura de linguagem importantíssima, que será marca registrada ao longo da obra Quando é dia de futebol, que é a ironia. Para falar sobre essas ironias no contexto da prosa de Drummond, tem-se, em primeiro lugar, o conceito de ironia, num ensaio intitulado "Breves considerações sobre o conceito de ironia, de Søren Kierkegaard", publicado na Revista Espaço Acadêmico, no dia 13 de maio de 2013, no qual a professora e pesquisadora Jacqueline Oliveira Leão analisa esse conceito de acordo com o filósofo:

\begin{abstract}
Dessa forma, a ironia manifesta-se no momento em que a palavra (fenômeno) se mostra em oposição ao pensamento (essência), e, no jogo irônico, o sujeito é negativamente livre, pois o enunciado não corresponde ao seu pensamento, sendo, ao contrário, distorcido do sentido imediatamente pretendido. A definição mais apropriada de ironia, segundo Kierkegaard, é "figura do discurso retórico, cuja característica está em se dizer o contrário do que se pensa". ${ }^{11}$
\end{abstract}

\footnotetext{
${ }^{10}$ A palavra "drible" está sendo usada, aqui, de maneira metafórica, como uma analogia entre os movimentos "poéticos" de um jogador, que rompem a linearidade da troca de passes e contrariam as expectativas de seu marcador, e os movimentos verbais de um poema, que quebram a organização racional da prosa e surpreendem o leitor.

11 LEÃO, 2013, p. 3.
}

https://periodicos.unifap.br/index.php/letras

Macapá, v. 6, n. I, Io semestre, 2016. 
Na crônica intitulada "O Importuno", publicada pelo Correio da Manhã no dia 13 de julho de 1966, o autor demonstra o valor que o cidadão brasileiro dá a um jogo de Copa do Mundo, principalmente quando está jogando a seleção brasileira, priorizando o futebol em detrimento de seu próprio trabalho:

- Que negócio é esse? Ninguém me atende?

A muito custo, atenderam: isto é, confessaram que não podiam atender, por causa do jogo com a Bulgária.

- Mas que tenho eu com o jogo com a Bulgária, faça-me o favor? E os senhores por acaso foram escalados para jogar? O chefe da seção aproximou-se apaziguador:

- Desculpe, cavalheiro. Queira voltar na quinta feira, 14. Quinta-feira não haverá jogo, estaremos mais tranquilos.

- Mas prometeram que meu papel ficaria pronto hoje sem falta.

- Foi um lapso do funcionário que lhe prometeu tal coisa. Ele não se lembrou da Bulgária. O Brasil lutando com a Bulgária, o senhor quer que o nosso pessoal tenha cabeça fria para informar papéis?

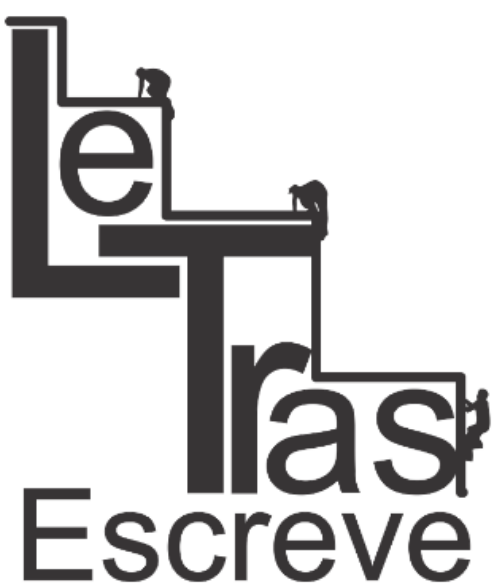

(ISSN 2238-8060)

- Perdão, o jogo vai ser logo mais, às quinze horas. É meio dia, e já estão torcendo?

- Ah, meu caro senhor, não critique nossos bravos companheiros, que fizeram o sacrifício de vir à repartição trabalhar quando podiam ficar em casa ou na rua, participando da emoção do povo...

- Se vieram trabalhar, por que não trabalham?

- Porque não podem, ouviu? Porque não podem. O senhor está ficando impertinente. Aliás, disse logo de saída que não tinha nada com o jogo com a Bulgária! O Brasil em guerra porque é uma verdadeira guerra, como revelam os jornais nos campos da Europa, e o senhor, indiferente, alienado, perguntando por um vago papel, uma coisinha individual, insignificante, em face dos interesses da pátria! ${ }^{12}$

A ironia está presente no texto justamente pelo fato de que Drummond, ao colocar os funcionários mais preocupados com o jogo do que com o próprio trabalho, reafirma uma crítica à falta de compromisso desses funcionários com o seu trabalho que, a princípio, seria muito mais importante. Ao mesmo tempo, o escritor elabora uma crítica em relação ao papel do futebol no país, pois, para o poeta, o jogo não deveria ser uma prioridade. Para fazer essa crítica, o autor se vale das liberdades do gênero cronístico,

${ }^{12}$ ANDRADE, 2014, p. 50.

https://periodicos.unifap.br/index.php/letras

Macapá, v. 6, n. I, Io semestre, 2016. 
aproximando-o de outras formas narrativas como o conto e a

parábola. A poeticidade, aqui, se insinua na prosa, na forma de uma ideia que aparece cifrada numa situação narrativa.

Continuando na análise dos dribles da ironia presentes nas crônicas de Drummond, apresento a crônica intitulada "Situações", publicada no Correio da Manhã no dia 05 de julho de 1958, na qual ele comenta a recepção dos jogadores campeões da Copa do Mundo de 1958 por parte do presidente Juscelino Kubitschek, que ao mesmo tempo pensa sobre a reforma de seus ministérios:

Bem, não pretendo estabelecer qualquer comparação, mas dias depois, no palanque armado para receber os campeões do mundo, nosso atual presidente, visivelmente satisfeito, mostrava sem embargo disso, uma ponta de inquietação, que me intrigou. Parecia estar e não estar ali, com um olho na multidão e outro na reforma do ministério. Dirigia a vista para um e outro lado, à procura do homem ou dos homens providenciais que lhe formassem uma grande equipe, do valor daquela que vencera no futebol, mas Garrincha e Vavá para a Agricultura e o Trabalho, isso não havia. Terá pensado um instante em convidar o próprio Vavá e o próprio Garrincha para essas pastas, mas será que eles aceitariam? Na dúvida, o presidente empunhava a Taça Jules Rimet ou deixava-a sobre o parapeito, não avaliando bem a preciosidade do troféu. Mas João Havelange, inquieto por sua vez, não com o destino do Brasil, e sim da taça, segurava-a de lado, e às vezes procurava erguê-la perante a multidão fascinada. Juscelino puxava para a esquerda, Havelange para a direita: um para baixo, outro para cima; e eu via a hora em que a taça caia, e era um problema internacional a mais, a ser resolvido de saída pelo novo ministro Negrão de Lima: quem pegou o troféu no meio do povo e o incorporou, já meio amassado mas reluzente de ouro e glória, ao seu acervo particular? Felizmente a bela Copa não chegou a cair; esteve quase; Havelange, Paulo de Carvalho e Bellini souberam defendê-la. Mas o presidente, do alto do seu palanque, estava meio dispersivo e aéreo. Não era de todo feliz, como Dutra entre os filósofos, na livraria de dona Vanna ${ }^{13}$.

De acordo com Drummond, Juscelino, apesar de condecorar os campeões do mundo e utilizar aquela vitória para propagandear um bom governo, estava preocupado com a composição de seu ministério, pois os nomes que tinha para os cargos públicos não

${ }^{13}$ ANDRADE, 2014, p. 27.

https://periodicos.unifap.br/index.php/letras

Macapá, v. 6, n. I, Io semestre, 2016. 


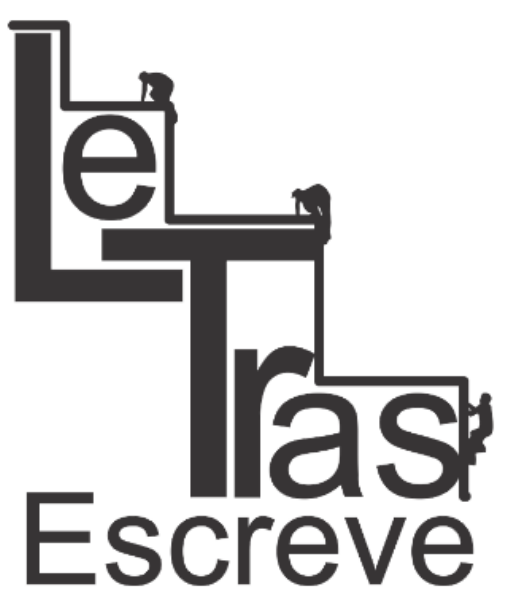

(ISSN 2238-8060) eram tão bons quando comparados com os nomes que a seleção brasileira tinha para ganhar o troféu. A frase inicial, em que o autor afirma que não pretende "estabelecer qualquer comparação" entre a seleção e o ministério, é claramente irônica, pois todo o trecho se ocupa, justamente, da relação metafórica entre o futebol e a política e da estranheza que essa relação provoca naquela situação.

Nos textos de Quando é dia de futebol, portanto, a relação entre o conceito de "futebol de prosa", proposto por Pasolini, e a escrita de crônicas e cartas pode ser feita em dois níveis. No nível apenas temático, Drummond se mostra um apreciador do futebol de poesia dos jogadores brasileiros, convergindo com a projeção no esporte da identidade cultural brasileira, e um crítico do "futebol de prosa" de muitos dos adversários da seleção nacional. Ao mesmo tempo, o poeta é também um crítico da excessiva importância que o futebol tem no país, assumindo uma racionalidade mais próxima da prosa do que da paixão esportiva que toma conta dos brasileiros.

Já no nível da escrita, das opções genéricas e dos modos de utilização da linguagem, temos textos em prosa, ligados a gêneros como a crônica e a carta, em que predominam a informalidade e a coloquialidade, bem como uma condução objetiva e direta dos temas e dos argumentos. Para se constituírem como literários, então, esses textos têm que conter alguns lances e elementos poéticos, que quebram a linearidade da prosa. Interessante lembrar, aqui, que a capacidade de extrair lirismo e poesia dos fatos banais do cotidiano é uma das marcas que o gênero cronístico adquiriu em sua rica trajetória no jornalismo e na literatura brasileira. ${ }^{14}$

\section{A poesia do futebol em Drummond}

Após analisar as relações entre a prosa do futebol e a prosa de Drummond, na obra Quando é dia de futebol, destacando algumas crônicas e cartas presentes no livro, abordarei neste

${ }^{14}$ CANDIDO, 1992, p. 13-22. 
segundo capítulo as relações entre o "futebol de poesia" e as poesias do autor, destacando os poemas presentes na obra e como eles podem ser relacionados com a teoria do cineasta italiano.

Para relembrar sinteticamente as características do "futebol de poesia", tem-se um comentário do professor e pesquisador da USP José Miguel Wisnik sobre Pasolini, que descreve da seguinte forma esse estilo de jogo:

Já o futebol poético suporia dribles e toques de efeito, ao mesmo tempo gratuitos e eficazes, capazes de criar espaços inesperados por caminhos não lineares, podendo o gol ser "inventado por qualquer um e de qualquer posição". Pasolini refere-se mesmo à "capacidade monstruosa" de driblar dos brasileiros, "os melhores fazedores de gols" do mundo. Sem disfarçar o seu entusiasmo de artista pelo futebol-arte, ressalva que a distinção entre futebol-prosa e futebol-poesia é especificamente técnica - semiológica -, e não valorativa, podendo cada um dos modos atingir ou não sua plenitude, impondo-se ao outro. Mas, no modelo poético - dominante, segundo ele, no futebol sul-americano -, o gol resultaria não de triangulações metodicamente concatenadas ou de cruzamentos com causa e efeito, mas de irrupções individualistas e de aproximações em ondas concêntricas, de cruzamentos paradoxais das causas com os efeitos, poderíamos dizer, cujo desenho intrincado dificilmente se deixaria reduzir a uma fórmula. ${ }^{15}$

Assim, a diferenciação dos modelos de "futebol de prosa" e "futebol de poesia" se dá, basicamente, pela qualidade técnica de (ISSN 2238-8060) cada estilo: o primeiro depende de jogadas coletivas e bem organizadas entre os jogadores para chegar ao gol; enquanto, no segundo modelo, o gol dependeria precisamente de um único jogador, com uma habilidade de dominar e conduzir a bola, elaborando, através dos dribles, uma jogada que retire os defensores do caminho, abrindo os espaços necessários para se chegar à meta final.

Continuando com a análise sobre o "futebol de poesia", Cornelsen faz uma observação a respeito da principal característica desse estilo de jogo:

${ }^{15}$ WISNIK, 2008, p. 116.

https://periodicos.unifap.br/index.php/letras

Macapá, v. 6, n. I, Io semestre, 2016. 
Outra característica do "futebol de poesia" seria o drible que, assim como o gol, seria sua expressão por excelência. Pasolini aponta como sublime uma jogada construída por uma longa sequência de dribles - uma sintaxe -, em que um único "podema" - unidade mínima da linguagem do futebol -, ou seja, o jogador com posse de bola, partiria do meio de campo até a meta e faria o gol. ${ }^{16}$

Ou seja, através do drible, a poesia se insere na prática do futebol. Para levar essa discussão para a leitura dos poemas de Drummond sobre o futebol, vejamos inicialmente algumas ideias, recolhidas nos textos de sua fortuna crítica, sobre as características gerais de seus textos poéticos. No livro Coração partido, de Davi Arrigucci Jr., tem-se uma explicação bem pertinente a esse respeito:

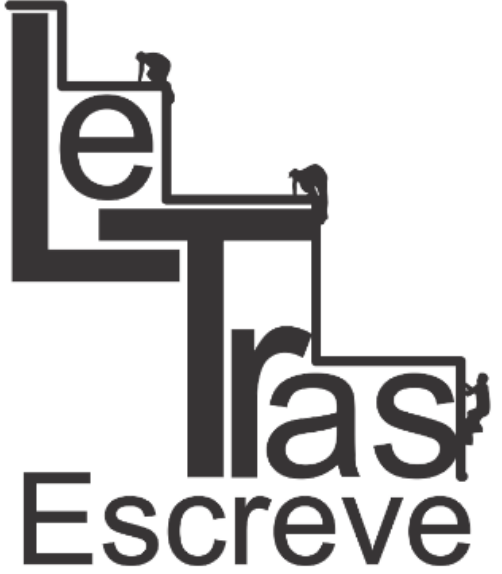

(ISSN 2238-8060)

E de fato Drummond é um grande poeta da sintaxe; não apenas pela habilidade inventiva que demonstra no tratamento e na combinatória interna das palavras da frase. Sabe criar com pouco um ritmo próprio, engendrando admiráveis sequências verbais. É senhor absoluto do instrumento de ofício. Na verdade, por associações inesperadas (num sentido amplo, mais maleável do que o da sintaxe da gramática tradicional), ele gera e organiza as relações entre verso e universo, por tudo o que é capaz de trazer de fora, do mundo e da linguagem, e coadunar, ritmicamente, no interior do poema. ${ }^{17}$

Segundo Arrigucci Jr., então, para conseguir organizar as palavras e dar ritmo a elas, elaborando poemas de amplo conteúdo e significação, o poeta depende de um "poder de articulação", por meio do qual ele mobiliza de um modo particular a sintaxe poética:

A capacidade de conjugar num poema múltiplas e heterogêneas esferas da realidade depende por certo da imaginação, entendida como faculdade plasmadora da arte, e se traduz materialmente num poder de articulação, de que depende, por sua vez, em profundidade, a forma artística.

Nesse sentido, desde o começo Drummond dá demonstração de sua força imaginativa pelo notável poder de articulação que demonstra, ou seja, pela capacidade artística de integrar a

${ }^{16}$ CORNELSEN, 2006, p. 185.

${ }^{17}$ ARRIGUCCI JR., 2002, p. 31.

https://periodicos.unifap.br/index.php/letras

Macapá, v. 6, n. I, Io semestre, 2016. 


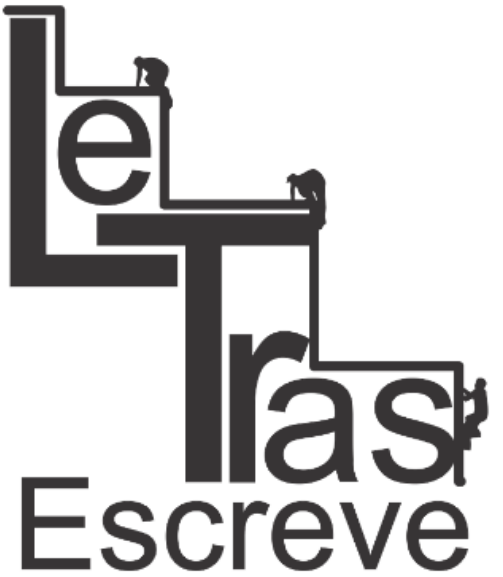

(ISSN 2238-8060) multiplicidade na unidade. A articulação, categoria estética central a toda a arte moderna, é uma chave para a compreensão de sua poética e tem precisamente no chiste uma primeira manifestação decisiva. ${ }^{18}$

É esse poder de articulação que permite a Drummond materializar na expressão poética a multiplicidade do mundo e seus ecos na sua interioridade, como argumenta Arrigucci Jr.:

Dar forma às coisas desencontradas que pululam no mundo e nunca deixam de pulsar junto com o coração batendo também em descompasso, perseguir o ressôo dos ecos de fora até os mais distantes fundos da alma, eis um desafio que desde o começo o poeta parece sentir, pois de fato já nasce com o malestar, o sentimento negativo da inadequação e da discórdia frente ao mundo dos tempos modernos. ${ }^{19}$

No poema que abre a obra Quando é dia de futebol, Drummond já demonstra esse "poder de articulação" mencionado por Arrigucci Jr., traduzindo sinteticamente seu pensamento sobre o esporte, que repercute na própria materialidade do texto:

uma paixão:

$$
\begin{aligned}
& \text { a bola } \\
& \text { o drible } \\
& \\
& \quad \text { o chute } \text { gol. }^{20}
\end{aligned}
$$

Percebe-se que o estilo de jogo chamado por Pasolini de "futebol de poesia" dialoga diretamente com o poema, pois, para falar sobre o esporte, o poeta utiliza apenas algumas palavras "soltas" no texto, prescindindo do encadeamento sintático típico da prosa. Além disso, essas palavras não estão na sequência usual da frase, pois elas vão "caindo" ao longo do texto, como se estivessem "driblando" o leitor. Porém, mesmo o texto possuindo essa construção poética, seu conteúdo está claramente organizado em relação à sequência do próprio jogo de futebol. Em primeiro lugar é

\footnotetext{
${ }^{18}$ ARRIGUCCI JR., 2002, p. 31-32.

19 Idem, p. 32.

${ }^{20}$ ANDRADE. 2014, p. 11.
} 


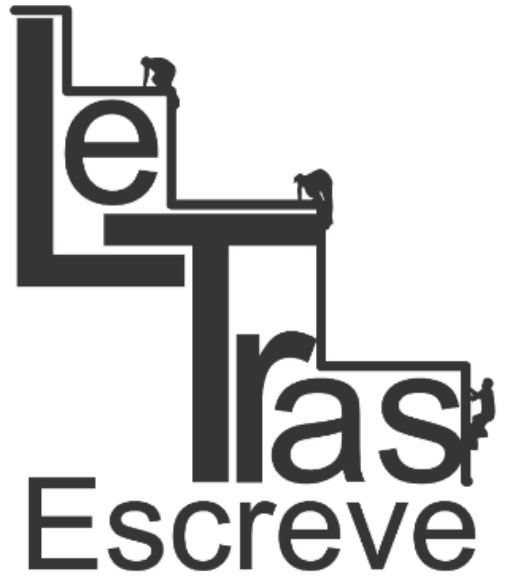

(ISSN 2238-8060) preciso ter paixão pelo esporte; para logo em seguida lidar com o seu material, que é a bola; para que depois a poesia possa entrar, através do drible; até que um "podema final", que seria o chute, possibilita chegar ao objetivo e à emoção maior desse esporte, que é o gol. Drummond apresenta as palavras nessa ordem, demonstrando as etapas da ação de um jogador até a meta final, numa escala crescente de importância.

Vejamos, agora, o segundo poema do livro, intitulado "Futebol", que nos leva a propor certas reflexões sobre como o poeta tematizava esse esporte:

Futebol se joga no estádio?

Futebol se joga na praia, futebol se joga na rua, futebol se joga na alma.

A bola é a mesma: forma sacra para craques e pernas-de-pau. Mesma a volúpia de chutar na delirante copa-mundo ou no árido espaço do morro. São voos de estátuas súbitas, desenhos feéricos, bailados de pés e troncos entrançados. Instantes lúdicos: flutua o jogador, gravado no ar - afinal, o corpo triunfante da triste lei da gravidade. ${ }^{21}$

Neste poema, pode-se perceber, logo no seu início, a sutileza com que Drummond aborda o futebol, pois coloca, lado a lado, o esporte sendo jogado tanto no estádio quanto na praia, na rua e na alma. Depois de questionar, no primeiro verso, o lugar onde se joga futebol, ele demonstra, logo em seguida, sua visão do futebol como um esporte democrático, graças à facilidade com que ele pode ser praticado em diferentes espaços físicos. Além disso, o caráter espiritual (alma) desse esporte deve ser destacado, visto que é preciso ter paixão e estar bem-disposto para apreciá-lo e praticá-lo. Daí o deslocamento metonímico, no quarto verso do poema, em que

${ }^{21}$ ANDRADE. Quando é dia de futebol, p. 13. 


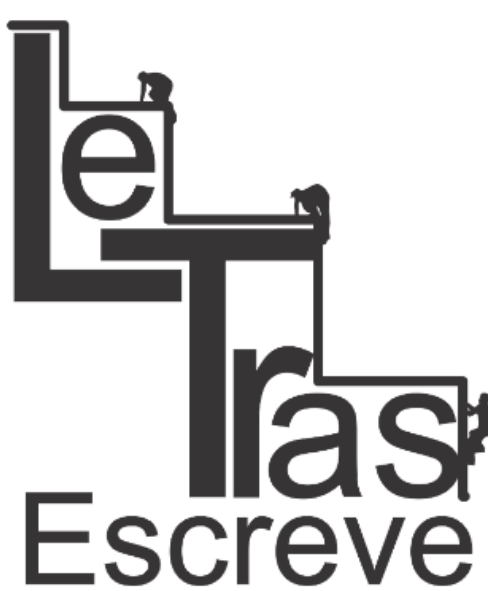

(ISSN 2238-8060)

a alma substitui o corpo na tarefa de jogar o futebol. Com as expressões "futebol se joga na alma" e "a bola é a mesma: forma sacra", Drummond coloca o futebol em dois planos que, embora distintos, se entrecruzam (entre o terreno e o espiritual), elevando-o a um patamar sagrado. Por meio dessa dualidade de planos, tem-se outra figura de linguagem, a antítese, que aproxima ideias contrárias no poema.

Nos versos "A bola é a mesma: forma sacra" e "para craques e pernas-de-pau", tem-se assinalado novamente 0 caráter democrático do esporte, visto que a bola é igual tanto para aqueles que sabem jogar quanto para aqueles que são "ruins de bola". Nos versos "mesma a volúpia de chutar", "na delirante copa-mundo", "ou no árido espaço do morro", apresenta-se, ao mesmo tempo, uma hipérbole, que exagera o fato de que o jogador tem uma grande vontade de chutar, e uma antítese, pois a ideia de se jogar bola na Copa ou no morro é uma oposição (remetendo a um conflito de classes sociais), com o objetivo, mais uma vez, de enfatizar o caráter democrático do jogo.

Ainda no mesmo poema, Drummond elabora metáforas para descrever os movimentos dos jogadores, afirmando que eles são "voos de estátuas súbitas" e "desenhos feéricos, bailados / de pés e troncos entrançados". Em sua plasticidade, o corpo do jogador é estátua, desenho e bailado, o que remete, no imaginário do leitor, a uma visão mágica do movimento, destacando-se assim a irrupção dos eventos não lineares e imprevisíveis, apontados por Pasolini, Wisnik e Cornelsen em seus textos. Os dois versos finais, em que o corpo do atleta triunfa sobre a "triste lei da gravidade", demonstram com clareza essa quebra da racionalidade da prosa.

Para continuar com a demonstração dos "dribles poéticos" na obra de Drummond, transcreve-se a seguir os versos iniciais e finais do poema "De 7 dias", publicado no jornal Correio da Manhã, no dia 22 de junho de 1958, tematizando Garrincha e Pelé, jogadores ainda em vias de consagração no futebol nacional e mundial: 
Começou festiva a semana:

espiávamos por uma frincha

a vitória, e eis que ela fulgura,

rosa aberta ao pé de Garrincha.

(...)

E vem outro, mais outro dia,

Paira a esperança, junto à fé.

A bola em flor no campo joia,

E seu ourives é Pelé. ${ }^{22}$

No fragmento acima, o "futebol de poesia" é poeticamente evocado pelas rimas entre "frincha" e "Garrincha", "dia" e "joia", "fé" e "Pelé", que constroem a musicalidade do texto, por meio da qual o autor consegue captar e transmitir ao leitor as intensas sensações do torcedor, associando, por exemplo, a fé dos brasileiros ao nome

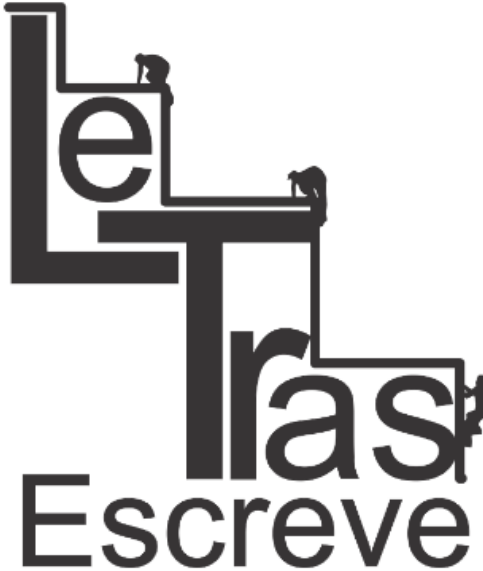

(ISSN 2238-8060) de Pelé. Garrincha e Pelé têm um relevo muito grande na obra de Drummond, não apenas sendo lembrados nos poemas, mas ganhando capítulos especiais dedicados a eles, intitulados "Pelé, o mágico" e "Garrincha, o encantador", além de o próprio Pelé ter escrito o prefácio do livro. Ainda em relação ao poema acima, nos terceiro e quarto versos da primeira estrofe, "a vitória, e eis que ela fulgura", "rosa aberta ao pé de Garrincha", apresenta-se a figura de linguagem da metonímia, pois a vitória da seleção brasileira está concretizada através das jogadas (e principalmente dos dribles) de um único jogador, Garrincha. Na última estrofe também se apresenta a metonímia, pois toda a esperança e a fé na vitória da seleção estão concentradas na construção das jogadas de Pelé. Registre-se, também, o processo de metaforização que transforma a vitória em uma rosa e a bola em uma joia, trabalhada pelo melhor ourives, Pelé.

Assim como Drummond, muitos outros escritores enalteceram o grande talento de Garrincha, um dos jogadores mais tematizados da literatura brasileira. $\mathrm{O}$ mais famoso deles é o jornalista e escritor Nelson Rodrigues, que o considera como "a única sanidade mental

${ }^{22}$ ANDRADE, 2014, p. 23-24.

https://periodicos.unifap.br/index.php/letras Macapá, v. 6, n. I, Io semestre, 2016. 
do Brasil". No trecho abaixo, o estilo intuitivo de Garrincha é mais um índice dessa oposição entre a racionalidade da prosa e sua quebra pelo estilo poético dos jogadores brasileiros:

Eu disse que Saldanha pensava. Pois acontece o contrário com Garrincha. Sim, amigos: Garrincha não pensa, nem precisa pensar. Saldanha ou qualquer outro vive do raciocínio. Nós pensamos todos os nossos atos. Não fazemos nada sem um penoso processo mental. Antes de atravessar a rua, ou de chupar um Chicabon, o homem normal é lacerado de dúvidas. Ele estaca diante da carrocinha amarela e, acometido por uma perplexidade hamletiana, pergunta, de si para si: - "Tomo ou não tomo o Chicabon? Talvez seja melhor não tomar 0 Chicabon. Ou devo tomar?" Em futebol a mesma coisa. Ao praticar um reles arremesso lateral, o jogador esbanja um tempo precioso ao escolher o companheiro que deve receber a bola. O ser humano pensa demais, e é pena, pois a vida é, justamente, uma luta corporal contra o tempo. Repito: - o ser humano vive pouco porque pensa muito. Ora, a máxima característica terrena de Garrincha é a seguinte: - ele não precisa pensar. E, por isso, porque não pensa, posso apontá-lo como a única sanidade mental do Brasil. ${ }^{23}$

No poema intitulado "Copa do Mundo de 70", publicado no Jornal do Brasil no dia 09 de junho de 1970, apresenta-se o torcedor de futebol Drummond, que se rende ao sentimento nacional em torno da seleção:

\section{I/ Meu coração no México}

Meu coração não joga nem conhece as artes de jogar. Bate distante. da bola nos estádios, que alucina o torcedor, escravo de seu clube. Vive comigo, e em mim, os meus cuidados. Hoje, porém, acordo, e eis que me estranho: Que é de meu coração? Está no México, voou certeiro, sem me consultar, instalou-se discreto, num cantinho qualquer, entre bandeiras tremulantes, microfones, charangas, ovações, e de repente, sem que eu mesmo saiba como ficou assim, ele se exalta e vira coração de torcedor, torce, retorce e se distorce todo,

${ }^{23}$ RODRIGUES, 2007, p. 476-477.

https://periodicos.unifap.br/index.php/letras

Macapá, v. 6, n. I, Io semestre, 2016. 
grita: Brasil! Com fúria e com amor. ${ }^{24}$

No poema acima, destacam-se duas figuras de linguagem, a personificação e a hipérbole. A primeira figura apresenta-se em quase todo o poema, pois Drummond personifica seu coração, atribuindo-Ihe características humanas. A mesma imagem pode ser lida também como uma metonímia, pois o coração simboliza o próprio poeta, assumindo a sua condição de torcedor. A hipérbole aparece no quarto verso, "o torcedor, escravo de seu clube", pois o poeta exagera ao demonstrar a relação apaixonante entre o torcedor e seu clube. No conjunto do poema, mais uma vez temos o conflito entre a racionalidade e a paixão despertada pelo futebol, conflito esse que é simbolicamente resolvido pelo triunfo poético da paixão.

Observa-se, assim, que os textos poéticos de Drummond apresentam diversos "dribles", que dão sabor e originalidade aos seus poemas. Além disso, esses dribles, inseridos nos textos poéticos sobre futebol, proporcionam ao leitor uma visão diferenciada do esporte na literatura, pois os movimentos do jogo se apresentam não apenas de forma descritiva, mas incorporados à própria estrutura dos poemas. Através desses movimentos, o leitor desloca o seu olhar, saindo do conteúdo em si, que seria o olhar comum, apenas absorvendo as informações, para os aspectos (ISSN 2238-8060) estruturais, tanto do texto quanto do próprio futebol. Concluo, então, este capítulo com o poema intitulado "A seleção", publicado no Correio da Manhã no dia 03 de abril de 1966, no qual o poeta comenta a escalação da seleção brasileira para a Copa de 1966, na Inglaterra. As rimas, assonâncias e aliterações, nesse poema, cumprem a função de simbolizar a harmonia e a união nacional, materializada pela seleção, que parte em busca de mais um título mundial:

Vai Rildo, não vai Amarildo?

Vão Pelé e, que bom, Mané,

${ }^{24}$ ANDRADE, 2014, p. 72.

https://periodicos.unifap.br/index.php/letras

Macapá, v. 6, n. I, Io semestre, 2016. 


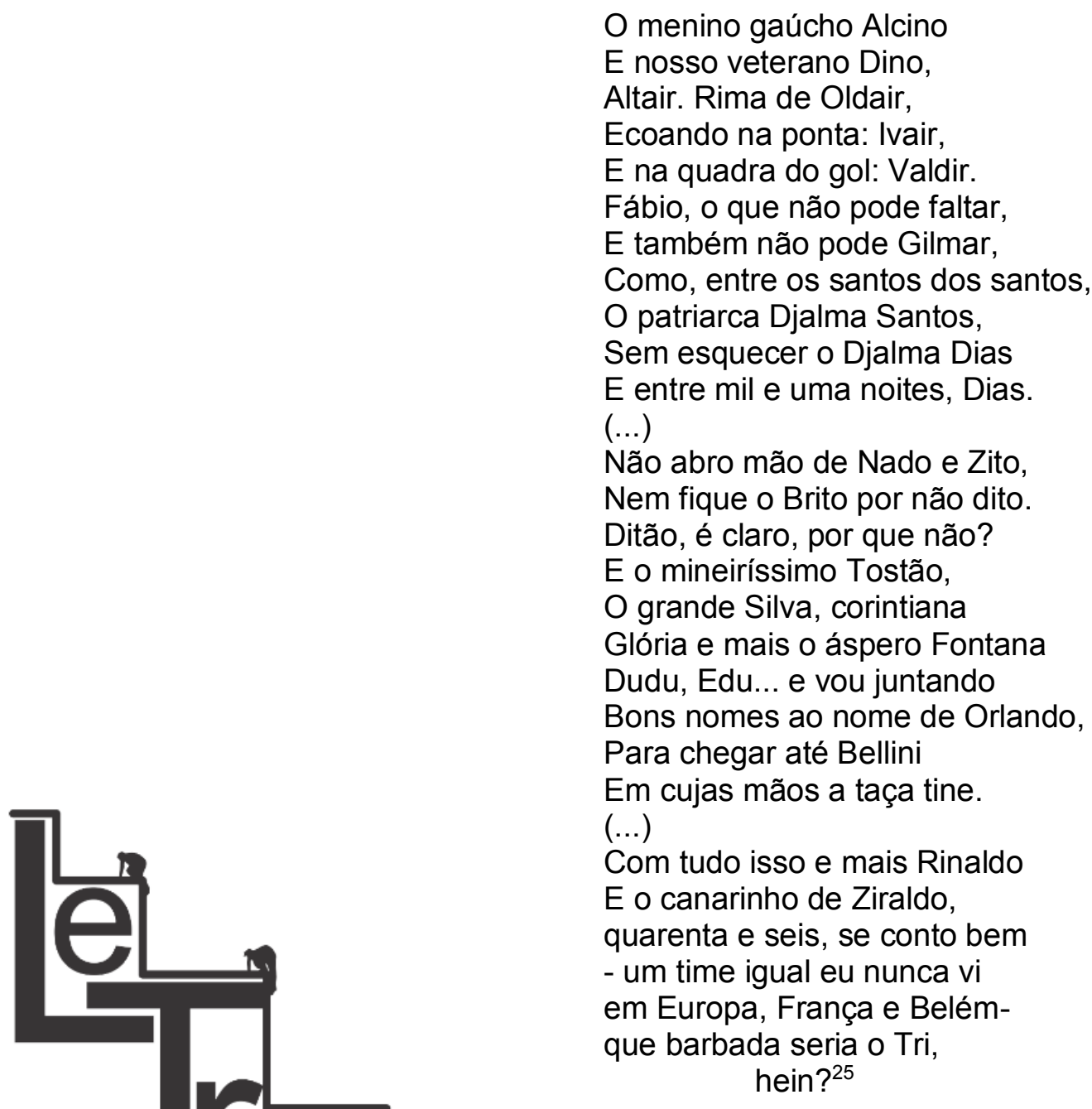

\section{Referências Bibliográficas}

(ISSN 2238-8060) ANDRADE, Carlos Drummond de. Quando é dia de futebol. São Paulo: Companhia das Letras, 2014.

ARRIGUCCI Jr., Davi. Coração partido - uma análise da poesia reflexiva de Drummond. São Paulo: Cosac \& Naify, 2002.

CANDIDO, Antonio. "A vida ao rés-do-chão". In: CANDIDO, Antonio et al. $A$ crônica: o gênero, sua fixação e suas transformações no Brasil. Campinas: Unicamp, 1992, p. 13-22.

CORNELSEN, Elcio Loureiro. "A linguagem do futebol segundo Pasolini: 'futebol de prosa'" e 'futebol de poesia'". Caligrama: revista de estudos românicos. v. 11. Belo Horizonte: 2006, p. 171-199.

${ }^{25}$ ANDRADE. Quando é dia de futebol, p. 46-47. 
CORNELSEN, Elcio Loureiro; FERREIRA, Luciane Corrêa; SILVA, Marcelino Rodrigues da (Orgs.). Aletria: Revista de Estudos de Literatura. v. 6. Belo Horizonte: POSLIT, Faculdade de Letras da UFMG, 2012.

LEÃO, Jacqueline Oliveira. Breves Considerações sobre o Conceito de Ironia, de Soren Kierkegaard. Revista Espaço Acadêmico (UEM), v. 13, p. 6-11, 2013.

PASOLINI, Pier Paolo. "O gol fatal". Folha de São Paulo, Caderno "Mais!", 6 de março de 2005, p. 4-5.

RODRIGUES, Nelson. O berro impresso das manchetes. Rio de Janeiro: AGIR, 2007.

WISNIK, José Miguel. Veneno remédio: o futebol e o Brasil. São Paulo: Companhia das Letras, 2008.

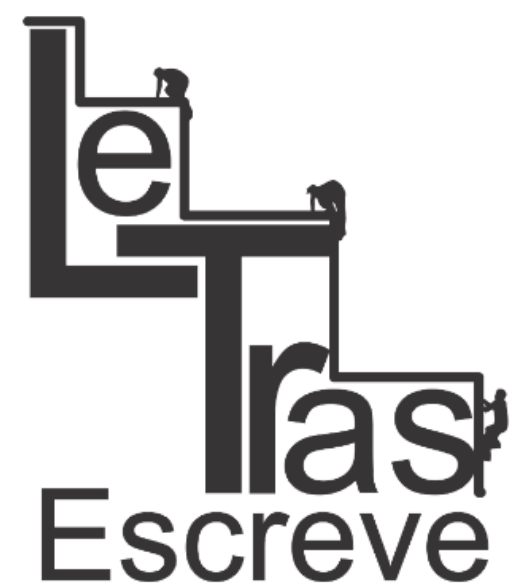

Recebido em 09/05/2016. Aprovado em 10/06/2016.

(ISSN 2238-8060) 